\title{
Sexually Transmitted Diseases in a specialized STD healthcare center: epidemiology and demographic profile from January 1999 to December 2009*
}

\author{
Epidemiologia e Perfil de Impacto das Doenças Sexualmente Transmissíveis atendidas \\ num Centro de Saúde Especializado de Janeiro de 1999 a Dezembro de 2009
}

\author{
Luiz Jorge Fagundes ${ }^{1}$ \\ Fernão Dias de Lima ${ }^{4}$ \\ Elso Elias Vieira Junior ${ }^{2}$ \\ Fátima Regina Borges de Morais ${ }^{5}$
}

\author{
Ana Carolina Marteline Cavalcante Moysés ${ }^{3}$ \\ Natalina Lima Vizinho ${ }^{6}$
}

DOI: $h$ ttp://dx.doi.org/10.1590/abd1806-4841.20132149

\begin{abstract}
BACKGROUND: Sexually Transmitted Diseases are still considered a serious public health problem in Brazil and worldwide. Oвјестіvе: To examine Sexually Transmitted Diseases prevalence and the sickness impact profile of STDs in a reference health center specializing in the treatment of Sexually Transmitted Diseases. METHOD: We collected epidemiological, demographic, clinical and laboratory data from the medical records and interviews of 4,128 patients who had attended the center from January 1999 to December 2009. ResulTs: Male patients outnumbered (76\%) females (24\%), Caucasians outnumbered (74.3\%) those of mixed race $(14.8 \%)$, blacks (10.8\%) and Asians (0.1\%). STD occurrence was higher in the 20-29 age group (46.2\%) This population included $34.7 \%$ high school graduates, $8.7 \%$ college graduates and $0.8 \%$ illiterates. As for affective-sexual orientation, $86.5 \%$ were heterosexual, $7.8 \%$ homosexual and $5.5 \%$ bisexual. Regarding patients' sexual practices over the previous 30 days, $67.7 \%$ reported sexual intercourse with one person, $8.6 \%$ had had sex with two persons and $3.9 \%$, with three or more people. The highest incidence of STD was condyloma acuminata, affecting $29.4 \%$ of all the patients, genital candidiasis $14.2 \%$, and genital herpes $10.6 \%$. Of the $44.3 \%$ who submitted to serologic testing for HIV detection $5 \%$ were positive, with a ratio of 6.8 males to 1 female. ConcLusions: STD prevalence remains high in Brazil and it is necessary to invest in early detection, prevention and treatment.
\end{abstract}

Keywords: Health services epidemiology; HIV seropositivity; Sexual behavior; Sexually transmitted diseases; Sickness impact profile

Resumo: Fundamentos: As Doenças Sexualmente Transmissíveis continuam sendo consideradas um grave problema de Saúde Pública no Brasil e no Mundo. OBJETIvo: Conhecer a epidemiologia de um serviço de saúde público brasileiro especializado em Doenças Sexualmente Transmissíveis e o perfil de impacto das principais doenças diagnosticadas nesse serviço. MÉTODO: Realizou-se a avaliação epidemiológica, clínica e laboratorial de 4.128 pacientes atendidos num ambulatório especializado em Doenças Sexualmente Transmissíveis, no período compreendido entre janeiro de 1999 a dezembro de 2009. ResultaDOs: Houve predomínio dos pacientes do sexo masculino (76\%) em relação aos do sexo feminino (24\%); da raça branca $(74,3 \%)$ sobre as raças parda $(14,8 \%)$, negra $(10,8 \%)$ e amarela $(0,1 \%)$. A ocorrência das Doenças Sexualmente Transmissíveis foi maior na faixa etária de 20 a 29 anos, com 46,2\%. Na população estudada, 34,7\% dos pacientes completaram o ensino médio, 8,7\% o curso superior e 0,8\% eram analfabetos. Em relação à orientação afetivo-sexual, 86,5\% eram heterossexuais, 7,8\% se relacionavam somente com pessoas do mesmo sexo e 5,5\% bissexuais. Em relação a prática sexual nos últimos 30 dias, 67,7\% declararam ter mantido relação sexual com apenas um parceiro, 8,6\% com dois e 3,9\% com três ou mais parceiros. As Doenças Sexualmente Transmissíveis de maior incidência foram o condiloma acuminado com $29,4 \%$ dos diagnósticos, a candidose genital com $14,2 \%$ e o herpes genital, com 10,6\% dos casos. Dos 44,3\% dos pacientes que realizaram o teste sorológico para detecção do HIV, $5 \%$ obtiveram resultado positivo, com razão de 6,8 homens para 1 mulher. ConcLusão: As Doenças Sexualmente Transmissíveis mantêm alta prevalência no Brasil, sendo necessário investir na detecção precoce, prevenção e tratamento adequado.

Palavras-chave: Comportamento sexual; Doenças sexualmente transmissíveis; Epidemiologia dos serviços de saúde; Perfil de impacto da doença; Soropositividade para HIV

Received on 22.09.2012.

Approved by the Advisory Board and accepted for publication on 16.10.2012.

Study conducted at the Sexually Transmitted Diseases Outpatients Department of the Escola Geraldo de Paula Souza Health Center of the Faculty of Public Health, University of São Paulo (CSEGPS-FSP-USP) - São Paulo (SP), Brazil.

Financial Support: None

Conflict of Interest: None.

Master and Ph.D. in Dermatology, Clinical Director of the "Escola Geraldo de Paula Souza" Health Center, Faculty of Public Health, University of São Paulo (CSEGPSFSP-USP) - São Paulo (SP), Brazil.

Post-Graduate Student (Ph.D. level), Pathology Department, Faculty of Medicine, University of São Paulo (USP). Specialist in Dermatology, Brazilian Society of Dermatology (SBD), São Paulo (SP), Brazil.

Master's degree in Infectious Diseases, Federal University of São Paulo (UNIFESP). Infectologist at Guarulhos General Hospital, the Santa Casa de Misericórdia de São Paulo/OSS and the Emílio Ribas Infectology Institute, São Paulo (SP), Brazil.

Specialist in Public Health, Systems Analyst, Epidemiology Department, Faculty of Public Health, University of São Paulo (CSEGPS-FSP-USP) - São Paulo (SP), Brazil. Biomedic in charge of the STD Laboratory of the Escola Geraldo de Paula Souza Health Center of the Faculty of Public Health, University of São Paulo (CSEGPS-FSPUSP) - São Paulo (SP), Brazil.

Nurse in the Escola Geraldo de Paula Souza Health Center of the Faculty of Public Health, University of São Paulo (CSEGPS-FSP-USP) - São Paulo (SP), Brazil.

(일 by Anais Brasileiros de Dermatologia

An Bras Dermatol. 2013;88(4):523-9. 


\section{INTRODUCTION}

Sexually transmitted diseases (STD) are infections transmitted mainly through sexual contact. Over 30 different types of bacteria, viruses and parasites are sexually transmitted, with the most common STD being gonorrhea, chlamydia, syphilis, trichomoniasis, chancroid, genital herpes, genital warts, human immunodeficiency virus (HIV) and hepatitis B. According to the World Health Organization, sexually transmitted diseases and their complications are among the top five diseases in developing countries which lead adults to seek health care. In young women of childbearing age, STDs (excluding HIV) are the second cause of disease-related death and loss of years of good health. The presence of an untreated STD may increase the risk of acquiring and transmitting HIV by a factor of approximately $10 .{ }^{1}$

There is insufficient data on STD prevalence in Brazil, especially among adolescents. The number of reported cases falls far short of the real estimates, given that only AIDS, HIV in pregnant women and newborns exposed to HIV and congenital syphilis are subject to mandatory reporting to the healthcare authorities. ${ }^{2}$ A further complication is that the majority of patients with some form of STD tend to seek treatment in pharmacies.

With the aim of investigating the sickness impact profile and epidemiological characteristics of STDs in patients presenting at a specialized health center in Brazil, a dedicated medical team from the Department of Sanitary Dermatology (São Paulo) undertook this study, which involved laboratory tests and epidemiological and clinical assessments of patients treated in the ten-year period January 1999 December 2009.

\section{MATERIALS AND METHODS}

This retrospective study involved the epidemiological, clinical and laboratory assessment of 4,128 patients in a specialized STD health care center between January 1999 and December 2009. The study was approved by the Research Ethics Committee (REC) of the institution where the study was conducted and the patients signed an informed consent form prior to their participation.

All patients had answered an epidemiological questionnaire and submitted to the following clinical, dermatological and specific laboratory tests and materials collection sessions,:

- Direct Gram stain in dark-field condenser, in an effort to detect spirochete with the morphology and motility typical of the genus Treponema;

- Bacterioscopy after staining by Gram's method to test for Gram-negative bacilli with morphotinctorial characteristics of the genus Haemophilus;
- Bacterioscopy after Leishman stain, with the purpose of showing giant cell with basophilic cytoplasm and multinucleation typical of viral herpetic inclusion;

- Bacterioscopy after Leishman or Giemsa stain to highlight Donovan corpuscles;

- Indirect immunofluorescence test for Chlamydia trachomatis, and non-treponemal serology Venereal Disease Research Laboratory (VDRL) and treponemal serology Fluorescent Treponemal Antibody Absorption (FTA-Abs) for screening and confirmation for syphilis diagnosis.

All patients who had signed the consent form were submitted to serological tests for the virus that causes acquired immunodeficiency syndrome (AIDS) HIV. The data obtained from the analyses of epidemiological, clinical and laboratory records had been collected in patients' own health centers. Diagnosed disease notification was effected in printed paper form and sent to the São Paulo State Health Secretariat.

Our results were expressed as frequencies and percentages (qualitative variables) or means and standard deviations (quantitative variables). To estimate interest percentage (prevalence), we constructed intervals of $95 \%$ confidence. In all statistical tests, we considered the significance level of 0.05 .

\section{RESULTS}

We present below the results of our epidemiological and clinical-laboratory evaluations of patients seen in a Brazilian specialized STD center from January 1999 to December 2009. The number of patients diagnosed with at least one STD, each year, is presented in graph 1.

During the period under study 4,128 patients were treated in the health center. The vast majority were male $(76 \%)$. Four records lacked gender information. Regarding racial characteristics, $74.3 \%$ (3,058 of the 4,128$)$ were Caucasian, $14.8 \%(611 / 4,128)$ of mixed race, $10.8 \%(445 / 4,128)$ were black and only one was Asian. 13 records did not indicate ethnicity.

STD occurrence was highest in the 20-29 years age group $(46.2 \%)$, followed by the $30-39$ years age group with $25.2 \%(1,041 / 4,128)$, the $40-49$ years group

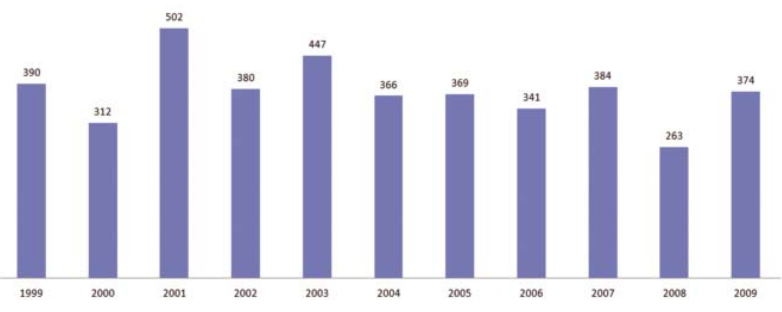

GRAPH 1: STD cases per year. Shows the number of patients diagnosed with at least one STD annually 
with $11.6 \%(480 / 4,128)$, the $10-19$ years group with $9.6 \%(400 / 4,128)$ and the $50-59$ years age group with $4.5 \%(188 / 4,128)$. The over-60s group had $2.4 \%$ STD occurrence $(101 / 4,128)$ and patients aged under ten years old represented $0.7 \%(3 / 4,128)$ occurrence.

Marital status of the patients on the first day in the center was as follows: $72.3 \%(2,981 / 4,128)$ were single, $23.7 \%(977 / 4,128)$ were married, $3.1 \%(128 / 4,128)$ were divorced and $0.8 \%(35 / 4,128)$ were widowed. Marital staus was not recorded for seven patients.

Since no reliable, measurable variable of socioeconomic status existed for these patients, we used education level data as an indicator of social stratification. At the time of their medical evaluation, $0.8 \%$ of patients $(34 / 4,128)$ were considered illiterate, $28.8 \%$ $(1,190 / 4,128)$ had not completed elementary school and $11 \%(453 / 4,128)$ had completed elementary school, $34.7 \%(1,433 / 4,128)$ had completed high school and $10.1 \%(417 / 4,128)$ had not, $5.4 \%$ $(222 / 4,128)$ had incomplete college education and $8.7 \%(361 / 4,128)$ had graduated.

As for affective-sexual orientation, $86.5 \%$ $(3,571 / 4,128)$ reported an exclusive sexual relationship with the opposite gender, $7.8 \%(323 / 4,128)$ had only same-gender sexual relationships $(98 \%$ men and $2 \%$ women) and $5.5 \%(227 / 4,128)$ of patients were recorded as having had sex with both genders. In this latter group, males accounted for $94 \%(213 / 227)$ and females for $6 \%(14 / 227)$. The total percentage of men recorded in our study who had sex with other men (MSM) was 13\% $(529 / 4,128)$. Seven records contained no data regarding affective and sexual orientation.

During the 30 days preceding their first visit, $18.9 \%(782 / 4,128)$ of patients reported no type of sexual relations, $67.7 \%(2,796 / 4,128)$ had had sex with only one partner, $8.6 \%(353 / 4,128)$ had sex with two partners and $3.9 \%(162 / 4,128)$ with three or more. Data was not available for 35 patients regarding the number of sexual partners in the 30 days prior to the first appointment. In the five years prior to their first visit, $0.5 \%$ of the patients $(21 / 4,128)$ said that they had no type of sexual contact and $18.4 \%(761 / 4,128)$ said they had had sexual contact with only one partner. Meanwhile, $12.7 \%(525 / 4,128)$ reported having had sexual contact with two partners, $13.6 \%(560 / 4,128)$ with three partners, $33.6 \%(1,389 / 4,128)$ with up to ten partners and, finally, $20.6 \%(851 / 4,128)$ reported sex with over ten different partners. 21 records contained no data on the number of sexual partners over the preceding five-year period.

Regarding STD diagnosis, $81.7 \%(3,374 / 4,128)$ of patients had one STD. Of these $77 \%(2,596 / 3,374)$ were male and $23 \%(768 / 3,374)$ female. Of the $18.3 \%$ $(754 / 4,128)$ patients with at least two other STDs, $70.5 \%$ (530/754) were male and 29.5\% (222/754) female.
Considering that some individual patients possibly had more than one STD, we assumed a total of 4,874 diagnoses. Graph 2 shows the proportion of diagnosed STDs. While no cases of donovanosis were reported during the study period, one case of congenital syphilis was however detected.

Tests were also performed to detect HIV in $44.3 \%(1,830 / 4,128)$ of our sample. From the total sample, $5 \%(210 / 4,128)$ returned positive results. In the HIV positive group, $87.1 \%(183 / 210)$ were male, with a male to female ratio (M:F) of 6.8:1 and a mean age of onset of 33.73 years (CI:32.59 to 34.88 ). 2.9\% $(118 / 4,128)$ of patients in our sample reported in their first medical visit that they were infected with the HIV virus or that they had acquired immunodeficiency syndrome. The average age of the latter group was 35.68 years (CI: 34.13 to 37.22$)$. $97.4 \%(115 / 118)$ were male. We found a total of $7.9 \%(328 / 4,128)$ from the sample with clinical and laboratory HIV seropositivity. Of these, $90.8 \%(298 / 328)$ were male, with a ratio M:F of 9.9:1.

Among men with clinical and laboratory HIV seropositivity, $42.6 \%(127 / 298)$ were MSM and $16.4 \%$ $(49 / 298)$ bisexual. In our sample of male patients with HIV, 59\% had had sex with other men, regardless of whether or not they also had sex with women. In this group $87 \%$ (462/529) underwent serological testing for the detection of antibodies against HIV. Of these $38 \%(176 / 462)$ tested positive.

\section{DISCUSSION}

STDs are considered to be a serious public health problem in Brazil. Unfortunately many health centers throughout the country lack appropriately trained medical and nursing staff to assist patients with these diseases. Medical teams are often not equipped to perform the specific tests. According to

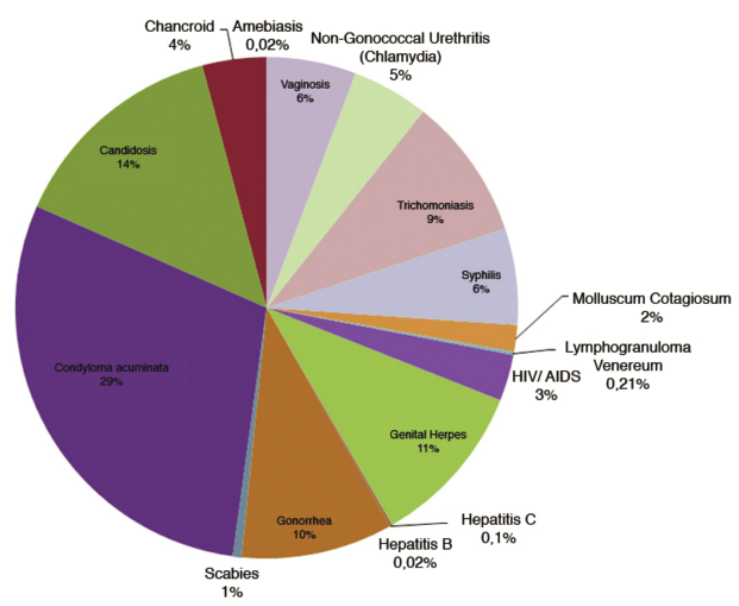

GRAPH 2: Proportional distribution of STD (total of 4,874 diagnoses, assuming the same patient with possibly more than one STD) 
data from the health surveillance authority of Brazil's most populous city São Paulo (the location of our study), the city possesses only a small number of reference sites devoted specifically to STD treatment: a total of 3 STD / AIDS Reference Centers (RC) and 10 Specialized Assistance Services (SAS). The CR services are of higher resolutivity, serving as a reference point for cases submitted by less complex services, while the SAS are devoted to prevention, diagnosis and treatment activities for people with STD / HIV / AIDS in outpatient and day hospitals. Sadly, bacterioscopic tests are not available in either of these services.

A further setback is that training and qualification in medical schools for working in the STD area is neither developed nor encouraged. In most medical teaching establishments students are often restricted to familiarizing themselves with the epidemiology and clinical manifestations of STDs on the basis of visual displays and commentaries during lectures.

In view of the shortage of dedicated health centers with the skills and knowledge to provide specialized medical care, and the reliance on non-specific medical staff for treating STD, many patients continue to seek advice on treatment and diagnosis from pharmacies (drugstores) and friends. While a prescription is needed for purchasing antibiotics in Brazil, it is not difficult to obtain these, with the result that self-medication is very common, particularly in the STD area. An interesting fact is that since 1980 around 3,200 residents in differing specialities from all over Brazil have passed through our center and have, during the evaluation of STD theoretical and practical knowledge, performed poorly on some of the basic STD and STD bacterioscopy laboratory issues. Furthermore it is clear that these residents were largely unfamiliar with the laboratory reagents used in STD work and knew little about standard methodologies of collection, staining and slides-reading. When tasked with their low performance ratings, the physicians unanimously admitted that they had attended only a few lectures on the subject, had attended no practical STD classes in their medical schools and that their faculties possessed no STD outpatient facilities or a dedicated bacterioscopy laboratory.

In Brazil, STD reporting in only mandatory for AIDS in general, HIV in pregnant women and exposed children, congenital syphilis and syphilis in pregnant women. ${ }^{3}$ Mandatory reporting of HIV positive pregnant women and of babies exposed to the virus is provided under Government Directive (Portaria) GM/MS $\mathrm{n}^{\circ} 5$ of February 21, 2006. ${ }^{4}$ Notification of other STDs is optional. ${ }^{3}$ It is therefore difficult to properly map and evaluate the STD epidemiological situation in Brazil, to implement relevant priority interventions, and to investigate and dis- cover any resistance to the therapies currently applied in Brazil.

In this study we observed a majority of male patients $(3,134$ patients). This was also the case in another study conducted in a STD specialized health center, where $71 \%$ of patients were male. ${ }^{5}$ In the latter, the authors advanced possible reasons for the predominance of male patients such as: the predominantly male clientele attending their clinic, female patients' preference for going to gynecology clinics to treat their disease, and the fact that the sexual intercourse that led to STD diagnosis in male patients was due, in most cases, to sporadic sexual relationships with no emotional bond.5,6 Meanwhile the São Paulo city health authorities reported slighly different results from our study: in the period 2007-2008 a total of 7,301 STD cases $-57.1 \%(4,172 / 7,301)$ in males and $42.9 \%(3,129 / 7,301)$ in females. $^{7}$

The predominance of Caucasian individuals in our study was significant $(74.3 \%)$, but while this did not directly indicate a link between STD and racial factors, we nevertheless concluded that an association certainly existed between STD and the socioeconomic circumstances of this group of patients. ${ }^{8}$

In educational terms, the majority of the patients had completed high school education. Among those in Brazil with HIV in 2009, $25.1 \%$ possessed 4-7 years of education, 30\% had around 8-11 years and $8.8 \%$ had approximately $1-3$ years. ${ }^{3}$ In a different survey of 35,000 male adolescents in the 17 to 20 years age range, it was observed that the lower the educational level, the higher the percentage of people infected by the AIDS-causing virus: e.g. the prevalence among males who had not completed elementary school was $0.17 \%$, while for those who had finished their schooling the percentage was $0.10 \%{ }^{9}$

In this study, the majority of patients, $46.2 \%$ $(1,915 / 4,128)$, with STD were aged between 20 and 29 years). Similar data were found in a study conducted in a STD specialized center, in which $62.4 \%$ of patients were between 20-29 years. Similar figures were obtained in a study conducted by the City of São Paulo, cited above. ${ }^{5,7}$ In the United States $50 \%$ of all STD cases occur among people aged 15 to 24 years. ${ }^{10}$

Given that individual patients may carry more than one STD, condyloma acuminata (CA) was the most prevalent disease in our study, responsible for $29.4 \%(1,436 / 4,874)$ of patients seekng medical care. According to the AIDS, HIV / STD and Hepatitis B and C Epidemic Update, 2009, condylomata acuminata was responsible in São Paulo for $38.7 \%$ of all STD notifications, followed by syphilis in adults $(23.1 \%$ of this population). ${ }^{7}$ It is also the most prevalent disease in the US, with 20 million people infected and an additional six million new cases a year. ${ }^{10}$ 
In the United Kingdom, condyloma acuminata incidence detected in genitourinary clinics increased by $30 \%$ over the ten-year period from 1999 to 2009 (70,414 diagnoses and 91,202 respectively) - currently the most common viral STD in that country. The highest rates of this disease were found in women aged 1619 years and in men aged 20-24. The number of diagnoses was almost three times higher in 1977-1986, but the increase was more gradual in subsequent years owing to changes in sexual behavior coinciding with increased AIDS rates in the early 1980s. In 2009, 83,373 condyloma acuminate cases were notified among men and 62,502 in women. ${ }^{11}$ Mirroring UK data, our study showed a higher number of patients with condyloma acuminata in males. Of the total sample, $29.4 \%$ of patients were infected with CA of which $82.8 \%$ $(1,190 / 1,436)$ were males.

Syphilis notifications, on the other hand, accounted for $6.2 \%(303 / 4,874)$ of our total population, ranking sixth among the most common STDs. Only one case of congenital syphilis (CS) was notified. CS became a reportable disease in Brazil in 1986. ${ }^{4}$ In 1993, Latin American countries proposed to eliminate CS from the list of public health problems, and established a basic incidence of one or fewer cases per 1,000 newborns. ${ }^{12}$ A study undertaken in Brazil's Amazon region of 674 pregnant women in a Tertiary Health Unit, revealed that $1.2 \%$ of the samples collected were VDRL positive, but only $1 \%$ of these cases were confirmed by treponemal test as congenital syphilis. ${ }^{13}$

Between January 1998 and December 2008, 4,300 cases of CS were reported in the City of São Paulo, with the lowest rate noted in $2006(1.8 / 1,000$ live births) and the highest in 2003 (2.5/1,000 live births). ${ }^{7}$ Even with the availability of standardized clinical guidelines, sophisticated diagnostic testing, various treatment options for pregnant women and good technical resources, CS diagnosis and inadequate prenatal care for pregnant women nevertheless remain seriously flawed in the Brazilian Public Health System.

Gonorrhea accounted for $9.8 \%(478 / 4,874)$ of all diagnosed cases in our center, with non-gonococcal urethritis (NGU), principally caused by chlamydia bacteria, responsible for $4.9 \%(241 / 4,874)$ of diagnoses. In contrast to the results of our study, chlamydia is the most prevalent STD among young people aged 16-24 years in the UK, accounting for $65 \%$ of all STD cases, followed by condyloma acuminata and gonorrhea. ${ }^{14}$ According to the UK Health Protection Agency (HPA), the increase in STD diagnoses in recent years was been largely due to the development of new diagnostic tests, as well as to continuing sexual risk behavior by the population. The lack of sex education from an early age and little awareness of STD has also contributed higher incidences of STD. ${ }^{11}$
With regard to HIV, among the STD patients who consented to blood tests for detecting antibodies, the seropositive prevalence rate of $5 \%$ was proportionally lower than that found in a study conducted in 1994-1998 in São Paulo. ${ }^{5}$ This data also differed substantially from that obtained by Brazil's Ministry of Health in 2005, which revealed a prevalence of $0.9 \%$ of HIV positive individuals in a sample of 2,911 men and women treated at STD specialized clinics in six different state capitals. ${ }^{15}$

In Brazil, recently published data classified São Paulo as one of the 100 Brazilian cities with the highest incidence of HIV-positive patients (31.2/100,000 inhabitants). Over the 10- year period 1999-2009 the AIDS incidence rate in the southeast region of Brazil decreased from 24.9 to 20.4 cases per 100,000 inhabitants, although that region still has the highest number of cumulative cases in Brazil (58\%).3 Among all our patients, we detected $7.9 \%(328 / 4,128)$ with a clinical/laboratory diagnosis of HIV seropositivity, mainly males $(90.8 \%, 298 / 328)$. Epidemiological data from 2009 showed the same higher prevalence for males, while indicating some prospect of the difference between the genders narrowing in future years. ${ }^{3}$ However, when we compared our study with data published by a specialized STD center in 1998, we observed that our study in fact showed an increase in the ratio of HIV among men. ${ }^{5}$ The 1998 data revealed a M:F ratio of 6:1, compared with 9.9:1 reported in our study (i.e. an increase in the proportion of men affected by HIV).

As for the affective and sexual orientation of people with HIV, $45.4 \%(149 / 328)$ in our study were heterosexual, $38.7 \%(127 / 328)$ were men who had sexual relations with men (MSM), and 15.5\% (51/328) were bisexual - 96\% (49/51) males and $4 \%(2 / 51)$ females. From these results we concluded that the majority $(53.6 \%$ or $176 / 328)$ of seropositive patients were MSM. This data reflected findings in the literature showing a higher prevalence of AIDS among specific populations such as the MSM group, injecting drug users (IDU), sex workers and prisoners. The data aslo confirmed that the greater the number of sexual partners, the greater the vulnerability to AIDS. ${ }^{16}$

The World Health Organization terms 'adolescence' as the period of life between 10 and 19 years of age - an important phase during which secondary sexual characteristics develop and when adolescents reach physical sexual maturity, along with the development of key psychological processes and the transition from dependency to relative autonomy. Given their initial lack of awareness and understanding of their own sexuality, coupled with sexual risk behavior and a lack of STD prevention knowledge, young people in this group are extremely vulnerable to sexually 
transmitted disease. ${ }^{17}$ According to a UNICEF survey $^{18,19}, 32.8 \%$ of Brazilians aged 12-17 have had sexual intercourse. In our study, $9.5 \%(395 / 4,128)$ of our patients were aged 10-19 years and were diagnosed with at least one STD, confirming the early onset of intercourse without the use of condoms. This group, vulnerable to sexually transmitted diseases, could represent a significant future public health problem. Among our adolescents, 59\% (232/395) were male and $41 \%(163 / 395)$ female, $93.1 \%$ (368/395) were single, $6.3 \%(25 / 395)$ were married and $0.5 \%(2 / 395)$ were divorced, $89.5 \%(353 / 395)$ were heterosexual, $6 \%$ (24/395) were bisexual and 4.5\% (18/395) were MSM.

Since even an adolescent can have more than one STD, the most prevalent disease among the 485 diagnoses was condyloma acuminata, accounting for $34.2 \%(166 / 485)$ of cases. Other common STDs were: $18.7 \%(91 / 485)$ with candidiasis, $12.3 \%$ (60/485) with vaginosis, $8 \%(39 / 485)$ with trichomoniasis and $7.8 \%$ (38/485) with gonorrhea. According to the Ministry of Health, human papillomavirus (HPV) and genital herpes were most prevalent among young people aged $10-24$ ( $25 \%$ and $17 \%$ respectively). ${ }^{20}$

Iin this age group, $1.2 \%(5 / 395)$ were carriers of HIV ( $60 \%$ male and $40 \%$ female). All the seropositive young men and boys were MSM. According to the latest Epidemiological STD and AIDS Bulletin, published by the Ministry of Health in 2010, the highest AIDS prevalence occurred in adolescents and young people aged 13-24 years, with males especially affected. Of 3,398 identified cases, 1,875 were males $(9.1 / 100,000)$ and 1,523 females $(7.5 / 100,000)$. The detection rate was 8.3 cases per 100,000 people. $^{3}$

Given that adolescents now tend to start their sexual life earlier than in previous generations it follows that educational, information and awareness programs on STD prevention need to be thoroughly explored and presented to children at an early stage in their development. It is vital for adolescents to start adopting approaches to sex which can enable them to enjoy their sexuality in a responsible manner.

\section{CONCLUSIONS}

Our results give some indication of the STD situation in Brazil and it is hoped that they might assist in establishing indicators for prevention, control and treatment. Our study may contribute to the development of health surveillance programs and encourage the further implementation of STD awareness programs. It should be entirely feasible to develop effective prevention programs rather than merely distributing condoms in the Primary Health Units and during large-scale Brazilian festivities such as carnival.

It is also important to avoid underreporting and focus on mandatory notification of all STD cases. Epidemiological data assembled in a methodical and structured way will allow us to map these diseases and help the authorities to plan more effective public health strategies accordingly. It should be possible to detect asymptomatic carriers at a very early stage in order to reduce the spread of STD, and point patients towards more effective treatment, resulting in quality of life improvement, better survival rates and less wastage of time and money on unnecessary interventions.

In addition to training and qualifying health professionals to treat STD patients, we must promote the further development of public programs aimed at controlling AIDS and other STDs. The health system needs to be in a position to implement prevention and emergency care strategies, and to ensure adequate therapeutic interventions and provision of resources while maintaining patient confidentiality and eschewing discriminatory attitudes. ${ }^{21}$

In common with other studies on the STD problem, our study confirmed that condyloma acuminata is the most prevalent STD. ${ }^{5,7,10,22}$ With the incorporation of HPV vaccines in the Brazilian Basic Vaccination Schedule, we hope to enjoy lower rates of STD in Brazil over the coming years (as well as their consequences). The high cost of this particular vaccine has hitherto put this method of prevention out of the question for the majority of the population.

An important key to lowering STD rates in Brazil is to ensure that parents, guardians, teachers and other educators have access to STD information programs which can be disseminated in different ways to the population at large. Thus everyone should be in a position to help inform at-risk individuals and groups of the need to change attitudes and dangerous sexual behaviors which can lead to sexually transmitted disease. 


\section{REFERENCES}

1. Who.int [Internet homepage]. Department of HIV/AIDS. Global prevalence and incidence of selected curable sexually transmitted infections: overview and estimates. Geneva, Switzerland; WHO 2001 [cited on 1 August 2011]. Available at: http://www.who.int/reproductivehealth/publications/rtis/HIV_AIDS_2001_2/en/

2. Taquette SR, Vilhena MM, Paula MC. Doenças sexualmente transmissiveis e gênero: Um estudo transversal com adolescentes no Rio de Janeiro. Cad. Saúde Pública. 2004;20:282-90.

3. Aids.org.br [Internet homepage]. Ministério da Saúde. Departamento de DST, AIDS e Hepatites Virais . Boletim Epidemiológico AIDS e DST 2010; 1(VII) p. 3-52. [Accessed on 1 July 2011]. Available at: http://www.aids.gov.br/

4. Ministério da Saúde. Secretaria de Vigilância em Saúde e Departamento de Vigilância Epidemiológica. Doenças Infecciosas e Parasitárias. Guia de Bolso. 8 ed. rev. Brasília: Ministério da Saúde; 2010. p.77-96.

5. Fagundes LJ, Patriota RCR, Gotlieb, SLD. Evaluation of the demand for the services of the Sexually Transmitted Disease Clinic of the Geraldo de Paula Souza Health Center, Faculty of Public Health, University of São Paulo, Brazil, during the period from 1994 to 1998. An Bras Dermatol. 2001;76:223-32.

6. Fagundes LJ. Sífilis adquirida recente: aspectos epidemiológicos, clínicos e terapêuticos [thesis]. São Paulo (SP): Faculdade de Medicina da Universidade de São Paulo; 1996.

7. Prefeitura da cidade de São Paulo. Boletim Epidemiológico de AIDS, HIV / DST e Hepatites B e C do Município de São Paulo - Ano XIII. N. 12. São Paulo: Secretaria Municipal da Saúde. DST/AIDS Cidade de São Paulo; 2009.

8. Cunha VF, Carvalho JPP, Belda W. Aspectos do problema da sífilis em duas unidades de atenção a gestantes na capital de São Paulo. An Bras Dermatol. 1983;58:63-6.

9. Aids.gov.br [Internet homepage]. Ministério da Saúde. Departamento de DST. AIDS e Hepatites Virais. AIDS no Brasil. [Accessed on 8 July 2011]. Available at: http://www.aids.gov.br/pagina/aids-no-brasil

10. Dunne E, Unger E, Sternberg M, McQuillan, G, Swan D, Patel S, et al. Prevalence of HPV infection among females in the United States. J Am Med Ass. 2007;297:813-9.

11. Hpa.org.uk [Internet homepage]. United Kingdom; c2010. STD Annual Slide Set 2000 2009. Health Protection Report (online series). [cited 1 August 2011]. Available at: http://www.hpa.org.uk/Publications/InfectiousDiseases/HIVAndSTIs/

12. Saraceni V, Domingos RMSM, Vellozo V, Laurua LM, Dias MAB, Ratto KMN, et al Vigilância da sífilis na gravidez. Epidemiologia e Serviços de Saúde. 2007;16:103-11.

13. Machado Filho AC, Sardinha JFJ, Ponte RL, Costa EP, Silva SSD, Martinez-Espinhosa FEM. Prevalência de infecção por HIV, HTLV, VHB, sífilis e clamídia em gestantes numa unidade de saúde terciária na Amazônia ocidental brasileira. Rev Bras Ginecol Obstet. 2010;32:176-83.

14. Hpa.org.br [Internet homepage]. United Kingdom; c2008. Sexually transmitted infections and young people in the United Kingdom: 2008 Report. [cited 1 August 2011]. Available at: http://www.hpa.org.uk/Publications/InfectiousDiseases/HIVAndSTIs/

15. Ministério da Saúde. Secretaria de Vigilância em Saúde. Programa Nacional de DST e Aids. Prevalências e frequências relativas de doenças sexualmente transmissíveis (DST) em populações selecionadas de seis capitais brasileiras, 2005. Brasília: Ministério da Saúde, 2008. p.83:146.
16. Hacker MA, Leite I, Friedman SR, Carrijo RG, Bastos Fl. Poverty, bridging between injecting drugs users and the general population, and "interiorization" may explain the spread of HIV in southern Brazil. Health Place. 2009;15:514-9.

17. Who.int [Internet homepage]. 10 facts on adolescent health. WHO 2008. [cited 2011 Aug 11]. Available from: http://www.who.int/features/factfiles/adolescent_health/en/

18. Ministério da Saúde. Coordenação Nacional de DST e AIDS. Prevenir é sempre melhor. Brasília: Ministério da Saúde; 2000. p. 39.

19. Fundo das Nações Unidas para a Infância - UNICEF. A voz dos adolescentes. Genebra: UNICEF; 2002.

20. Ministério da Saúde. Secretaria de Atenção à Saúde. Departamento de Ações Programáticas Estratégicas. Marco teórico e referencial: saúde sexual e saúde reprodutiva de adolescentes e jovens. Brasilia: Ministério da Saúde. 2007. p.56.

21. Giraldo PC. Doenças sexualmente transmissíveis: transcendendo as aparências. J Bras Doenças Sex Transm. 2006;18:99.

22. Aids.gov.br [Internet home page]. Ministry of Health, STD, AIDS and Viral Hepatitis 2008 [accessed on 1 August 2011]. Manual de Prevenção das DST/HIV/AIDS em Comunidades Populares. Ministério da Saúde. PN-DST/AIDS. Série manuais 2008. [accessed on 1 August 2011]. Available at: http://www.aids.gov.br/search/apachesolr_ search/Manual

How to cite this article: Fagundes LJ, Vieira EE Jr, Moysés ACMC, Lima FD, Morais FRB, Vizinho NL. Sexually Transmitted Diseases in a specialized STD health care center: epidemiology and demographic profile from January 1999 to December 2009. An Bras Dermatol. 2013;88(4):523-9. 